\title{
EDITORIAL
}

\section{Circumscribed journeys through soundscape composition}

The soundscape composition is the journey that circumscribes the relationship, the conversation between composer and sound sources. (Hildegard Westerkamp)

Environmental sounds hold an unusual place in our imaginations. On the one hand, they make up the often unnoticed ambiences of our daily lives: they are so much with us and surrounding us that it takes a special effort to bring them into the foreground, and pay attention to them. On the other hand, environmental sounds form a powerful conduit to memory. Hearing a particular sound or ambience can launch a chain of related memories, whether experienced consciously or working subconsciously, that reconnects us with particular places and times in our lives. It is precisely these confluences of memory, time and place that interest those who compose with soundscapes.

Soundscape composers listen to the relations of people and other inhabitants of places, producing pieces which are sonic expressions of not only landscape formations and lived environments but also the daily social histories and political organisation of the space. Philosopher Edward Casey says that places have a holding power, a tendency to gather:

Minimally, places gather things in their midst - where 'things' connote various animate and inanimate entities. Places also gather experiences and histories, even languages and thoughts. Think only of what it means to go back to a place you know, finding it full of memories and expectations, old things and new things, the familiar and the strange, and much more besides. What else is capable of this massively diversified holding action? (Casey 1996: 24)

These places are not inanimate containers in Casey's account, but actively gather experiences, histories and languages, and express them to listeners.

Soundscape composers can act as interpreters of the various languages of places, based on their knowledge of these places which is honed through the processes of listening, recording and composing. It is for this reason that soundscape composers talk of beginning the composing work not when they enter the studio, but when they first come to a place and begin listening to it. They can then use microphones as prostheses, extending listening, and providing both a recording of a sound experience as well as the possibility of reflection on that sonic experience through the mediations of memory, ideology and technology.

Soundscape composers remain concerned with connections among soundscapes and subjectivities through sonic memories. In a recent article on music and memory at the millennium, Jody Berland and Will Echard assert that selves are primarily constituted through memory: 'some psychologists assert that individual personality is largely comprised of memories of past experience, so that a person without memory is a person without self' (Berland and Echard 2001: 2). Of course, selves are constituted through a nexus of different experiences and so soundscape compositions are therefore interpreted by listeners differently, with responses that reflect individual personal histories with some common threads of meaning.

All of the processes involved in soundscape composition, from listening to recording, composition, and reception, are deeply enmeshed in issues of time, memory and place. The articles in this issue of Organised Sound discuss some of the approaches followed by soundscape composers throughout the history of the genre, the teaching of soundscape composition as part of music education, ethnography as a compositional basis for soundscape work, the reception of soundscape composition by listeners, the relationship of soundscape composition with acoustic ecology, and the production of two specific soundscape pieces.

Barry Truax' article presents a history of the compositional approaches of members of the World Soundscape Project, which pioneered soundscape research in the 1970s, led by composer R. Murray Schafer. As a member of that research team, and subsequently a wellknown international composer, Truax is particularly well placed to discuss this work. He analyses a number of influential pieces, describing them in relation to a continuum of found sound to abstracted techniques of composition, and referring to works by Hildegard Westerkamp, Denis Smalley, Peter Manning and several others. Particularly interesting in this article is Truax' discussion of different aural perspective explored by composers, including fixed, moving and variable spatial perspectives emphasising different time flows, and aural journeys. 
Gabriele Proy discusses how recording materialises sound, and separates it from its source. She uses semiotic theory to articulate some differences between Pierre Schaeffer's sound object or objet sonore of musique concrète, and Murray Schafer's sound event, which considers sound in its context.

Thomas Regelski proposes the teaching of 'organised sound composition' as a pedagogical improvement to existing musicianship education, which he argues is rooted too much in the past and not enough in contemporary composition techniques and aesthetics. Soundscape composition is one of the genres that he suggests as a way of introducing music students to the potentials of creating with sound, while avoiding the dogma of traditional music theory.

John Drever questions the conventional grouping of soundscape composition with acousmatic music, and instead considers ethnography as an approach particularly suitable to soundscape composition. He describes fundamental principles and approaches of ethnography, including its embrace of the subjective sensuous experience of the researcher. He critiques the problems and challenges of ethnography for composition, the ethics of representation that structure who is being represented to whom and in whose language, in other words who gets to speak? Drever then examines Steven Feld's work with the Kaluli people, and the resulting rainforest soundscape recordings, as an example of how an ethnographic approach to composition can work.

A further intervention of ethnography in soundscape composition is through the analysis of listener responses. Two of the articles in this soundscape issue of Organised Sound are reception studies, both of works by Hildegard Westerkamp. David Kolber analyses Kits Beach Soundwalk, a work that demystifies the process of studio composition, bringing attention to the way that technology allows us to idealise soundscapes. Kolber discusses how this piece increases his awareness of urban sounds, challenging him to re-evaluate the acoustic landscape while offering alternatives. My contribution to this collection is an analysis of Westerkamp's Cricket Voice. While Westerkamp aims to bring listeners closer to the sounds around them, some listeners feel fear and anxiety rather than the heightened closeness and understanding that she wishes people to experience. In this article, I compare my own analysis of this piece with the responses of a group of young listeners who write about alien encounters. I then consider the dramatic use of insect sounds in science fiction film soundtracks, to situate these responses in relation to popular media as well as to Westerkamp's work. I raise questions about how popular media dramatisations of intimacy with nature might simultaneously reflect and intensify urban anxieties about the sounds of 'alien' species that are associated with wilderness environments.

Hildegard Westerkamp's own article discusses several issues that she is presently considering in relation to contemporary soundscape composition. She completed this article just before speaking in Montrèal recently. When I read it shortly after her visit, I was amazed at how she had anticipated the very questions that young composers and sound artists were asking her that day about soundscape composition: Can you call a piece a soundscape composition if it is made from sound effects CDs? Does it make a difference? How well do soundscape composers know the places that they record? What do you need to think about when you are recording an unfamiliar culture? Westerkamp questions the image of sound environment as material resource and instead challenges soundscape composers and listeners to become more active acoustic ecologists. Like Drever, Westerkamp challenges the description of soundscape composition as similar to musique concrète. Westerkamp asserts that soundscape composition begins with conscious listening and awareness of our role as soundmakers. This is awareness of sound in context: unlike with the sound object of musique concrète, sound is not isolated but forms part of an environment that shapes it. The sound environment has rhythms, forms and atmospheres that shape the composer's decisions in the studio, just as the composer shapes the sound. Attention to the sound environment takes place throughout composition, from initial listening, through recording and studio work to the presentation of the piece.

We considered Hildegard Westerkamp's work at length because she is arguably the most prolific, and certainly one of the most experienced soundscape composers working today. We also include a more detailed description of the creation of two soundscape works by contemporary artists working in two quite different contexts. In 'Creating the soundscape for Zagreb everywhere', David Hahn works as a visitor with the soundscape of a place that he knows well. He has visited Zagreb in Croatia (formerly part of Yugoslavia) several times for several months each time, and is concerned to present a different image from that of the 'barbaric Balkans' promulgated in the media. Collaborating with a writer and a video artist to create a soundscape-based video, the artistic team wanted to try to communicate something about the city to people outside of Croatia, by producing an unorthodox presentation with multi-layered sounds, words and images. He discovers the limitations of a low-tech approach, while exploring resonance and respect as the basis of a compositional relationship.

Focusing on a North American urban environment, Reynold Weidenaar describes the production of a multimedia work based on the soundscape of Jones St. in Manhattan. In this article, there is a much more detailed explanation of recording techniques and compositional processing, with less emphasis on the composer's experience of place or relationships with its inhabitants. The compositional accounts of Weidenaar and Hahn then articulate two very different approaches that may 
be found in contemporary soundscape work, illuminating many of the themes and questions about ethics, technologies and representation raised by Truax, Drever, Westerkamp and myself. It is certain that many other soundscape composers could contribute their own commentary on these themes and questions. Such discussion and debate is one of the aims of this special collection, and we look forward to your responses.

Andra McCartney

\section{REFERENCES}

Berland, J., and Echard, W. 2001. Music and memory at the Millennium. Topia 6(Fall).

Casey, E. 1996. How to get from space to place in a fairly short stretch of time: phenomenological prolegomena. In S. Feld and K. H. Basso (eds.) Senses of Place, pp. 13-52. Santa Fe, NM: School of American Research. 
